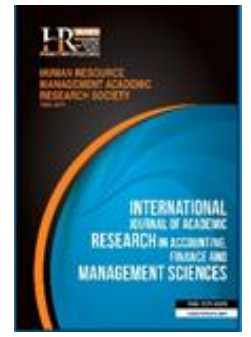

International Journal of Academic Research in Accounting, Finance and Management Sciences

Vol. 9, No.1, January 2019, pp. 150-159

E-ISSN: 2225-8329, P-ISSN: 2308-0337

(C) 2018 HRMARS

www.hrmars.com

To cite this article: Pernamasari R. (2019). Analysis of Index Internet Financial Reporting. Studies in Banking Companies in Indonesia, Malaysia and Singapore, International Journal of Academic Research in Accounting, Finance and Management Sciences 9 (1): 150-159.

\title{
Analysis of Index Internet Financial Reporting: Studies in Banking Companies in Indonesia, Malaysia and Singapore
}

\begin{abstract}
Rieke Pernamasari
Accounting Program, Economics and Business Faculty, Mercu Buana University - Meruya Selatan no. 1, West Jakarta, 11650, Indonesia.E-mail: rieke.pernamasari@mercubuana.ac.id
\end{abstract}

\begin{abstract}
The purpose of this study was to determine the differences in the internet financial reporting (IFR) index in banking companies in ASEAN, especially in Indonesia, Malaysia and Singapore. The IFR index method is used to measure content components, timeliness, technology and user support. The technique of collecting data used for this research is the technique of data source documentation using secondary data, namely company documents in the form of financial statements published on www.idx.co.id, www.bursamalaysia.com and www.sgx.com, and related company websites. The results showed that the quality of Internet Financial Reporting (IFR) in Banking in Indonesia was better than Malaysia and Singapore both in whole and quality in the components of Content, Timeliness, Technology and Use Support. This website of banking companies in Indonesia is more complete in presenting financial information even though on average only two languages are displayed (Indonesian and English). Although it has been quite good at providing support to users in accessing the company's website, the company does not apply much technology to its website, because it displays more banking products sold. While the websites of banking companies in Singapore and Malaysia, in addition to presenting financial information in PDF form, are also lacking in applying the use of technology on the company's website.

Key words

Internet Financial Reporting, IFR, Banking, Indonesia, Malaysia, Singapore

Received: 15 May 2019 (c) The Authors 2019

Revised: 30 May 2019 Published by Human Resource Management Academic Research Society (www.hrmars.com)

Accepted: 15 Jun 2019 This article is published under the Creative Commons Attribution (CC BY 4.0) license. Anyone may Published Online: 26 Jun $2019 \quad \begin{aligned} & \text { reproduce, distribute, translate and create derivative works of this article (for both commercial and } \\ & \text { non-commercial purposes), subject to full attribution to the original publication and authors. The full }\end{aligned}$ terms of this license may be seen at: http://creativecommons.org/licences/by/4.0/legalcode
\end{abstract}

\section{Introduction}

The increasingly rapid technology makes the internet a solution for companies in presenting financial reports. Annual financial reports are the main media for delivering information by company management to parties outside the company and quality financial reports must be able to provide relevant and reliable information in making economic decisions and investment decisions for stakeholders. Pratiwi et al. (2018) said that through technology companies can easily present company financial reports, distribute financial statements that are not in one geographical area, so that financial report users can easily access and print financial reports. One way for companies to report on the company's financial information is through Internet Financial Reporting (IFR).

The graph above is data obtained from Internet World Stats in 2018, Asia ranks the highest in internet usage in the world. The percentage of Asia in taking the portion of internet usage is $49 \%$, and the second place is in the European region of $16.8 \%$. This large percentage illustrates that Asians rely heavily on the internet for information. 


\title{
Internet Users in the World by Regions - June 30, 2018
}

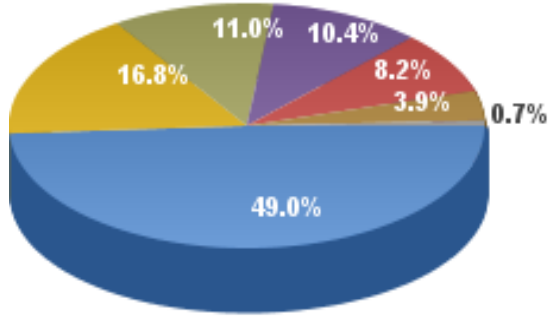

\author{
Asia $49.0 \%$ \\ Europe 16.8\% \\ Africa. $11.0 \%$ \\ Lat Am / Carib. 10.4\% \\ Worth America $\mathbf{8 . 2} \%$ \\ Middle East $\mathbf{3 . 9} \%$ \\ Oceania / Australia $0.7 \%$
}

Source: Internet World Stats - mww.internetworldstats.com/stats.htm

Basis: 4,208,571,287 Internet users in June 30, 2018

Copyright@ 2018, Miniwatts Marketing Group

This rapid development in information and communication technology has encouraged companies in many countries to consider the impact of the Internet on the delivery and dissemination of business information. This demand has resulted in the evolution of financial reporting, shifting from the conventional print-based way to modern Internet-based reporting (Al-Htaybat, 2011) to Ariff et al. (2018).

Wiwik and Lucky (2017) said that in making investment decisions, investors can analyze their investments using two methods of analysis, namely fundamental analysis and technical analysis. The results show that Indonesian investors prefer technical analysis and the factors that influence that the choice of analysis method significantly is the investor experience and investor's time horizon. So that information on the web will also influence investor decisions. Mohammadi (2014) in his paper stated financial reporting is one of the most important products of accounting system that tries to provide necessary information for users to make economic decisions on the evaluation of an economic enterprise's profitability and performance. The importance of financial information quality increases hundredfold in the event of some certain financial and nonfinancial events. The importance of financial information quality increases hundredfold in the event of some certain financial and nonfinancial events.

Based on a survey conducted by Khan (2006) on Amilia and Handayani (2013) of 1000 large companies in Europe showed that 67 percent of companies already had websites and 80 percent of companies that had websites revealed financial reports on the internet. In addition, research (Aly et al. 2010) revealed 56 percent of companies in Egypt reported most of the information on the company's website.

Dolinsek et al. (2014) on Reskino and Nova (2016) found that $52.6 \%$ of companies published accounting information on their websites and that on average $40.2 \%$ of users actually used this information by evaluating four characteristics: reliability, credibility, usability and adequacy on average. Users generally want information that shows the company's financial status (such as Report Valuation and company liquidity data), because information is currently expected by users but the information available does not meet their needs in full. Harnovinsah and Alamsyah (2017) said that the company's profitability information contained in finance is needed by investors to measure the return on investment and assess the risks / losses that might occur.

Pertiwi (2017) takes Islamic banks throughout the ASEAN region, namely 32 Islamic banks as research targets. The results of descriptive research statistics show that the average Islamic bank in the ASEAN region has not fulfilled the IFR index maximally, as evidenced by the average IFRI value of only 11.90, while if a bank fulfills all the requirements required in the index IFR, the maximum number that can be obtained is 18. The most complete disclosure of information through the website is Alliance Islamic Bank Berhad in Malaysia, while the most incomplete disclosure is Asian Finance Bank Berhad in Malaysia as well.

The development of technology and information not only shows the form of corporate transparency, but Ojah and Mokoteli (2012) in his research on 44 developed and developing countries resulted in IFR in the context of financial reporting economics as a means of dealing with agency problems. of the two dominant corporate governance models. Furthermore, Ojah and Mokoteli (2012) say there is strong evidence that state infrastructure determines the tendency of countries to disclose IFR, including computer 
or telecommunications infrastructure, the scope of financial (economic) markets, political and legal institutions.

Based on the background that has been described, the problem is determined whether there are differences in IFR index and component content, timeliness, technology and use support in banking companies in Indonesia, Malaysia and Singapore?

The purpose of this study is to see how much the difference between the IFR index and content components, timeliness, technology and use support in banks in Indonesia, Malaysia and Singapore. So that it is expected that the results of this study will provide information on the company's website so that information users can easily find all the necessary information related to the company without incurring high costs.

\section{Literature review}

\subsection{Stakeholder Theory}

Ulum (2017) reveals that based on stakeholder theory, organizational management is expected to carry out activities that are considered important for stakeholders and report back those activities to stakeholders. This theory states that all stakeholders have the right to be provided with information about how organizational activities affect them (for example, through pollution, sponsorship, security initiatives, etc.). The main aim of this theory is to help corporate managers understand the environment of their stakeholders and manage more effectively between the existences of relationships in their corporate environment. The broader purpose of this theory is to help corporate managers improve the value of their activities, and minimize losses for stakeholders.

\subsection{Signaling Theory}

Signal theory suggests how companies should provide signals to users of financial statements. This signal is in the form of information about what has been done by management to realize the wishes of the owners, Handayani and Almilia (2013). Signal theory can also be used to predict the quality of corporate disclosures, that is, by using the internet as a media for corporate disclosure, it can improve the quality of disclosure. So that the submission of financial statements carried out by management can be considered as a signal, which means that whether the agent has acted in accordance with the contract or not.

\subsection{Internet Financial Reporting}

Internet Financial Reporting (IFR) is a voluntary disclosure carried out by the company. But in its implementation there are no rules that regulate clearly and in detail. The application of Internet Financial Reporting (IFR) is carried out in accordance with the objectives of each company, namely for reporting financial information and other company information which will later be considered to be able to help increase the credibility of the company, Widari et al. (2018). Company information disclosed through the Internet helps users, especially small or foreign investors who do not have direct access to company financial information.

The company is said to have quality IFR if the company's website uses technology well and reports all financial information in accordance with the Internet Financial Reporting (IFR) index. IFR index component between: Content (content) This category includes components of financial information, such as annual reports, quarterly reports, financial statements that include balance sheets, income statements, cash flow statements, reports on changes in financial position, financial statement notes, auditor reports, and company leadership reports and corporate social responsibility reports. Financial information disclosed in HTML will get a higher score than in PDF, because the use of HTML format will make it easier for users to access company financial information more quickly. Besides that the element of language is an important addition to the index, because IFR is disseminated throughout the world, companies that disclose information using English, can expand communication. The higher the content component, the higher the index with a maximum score of 50 or $40 \%$.

Timeliness, this category relates to the timeliness of the company in updating information and data on the company's website such as press releases, stock quotes, latest unaudited quarterly reports, vision or forward-looking statements and graphs of expected future benefits. This category of timeliness is said to be 
of quality if the company presents information on the company's website in a timely manner. The more timely the company is in updating information and data, the index will be higher with a maximum score of 17 or 20 percent.

Technology, this category is related to the components of the use of technology used, such as the use of multimedia technology, analysis tools (such as Excel's Pivot Table), presentation slides, and advanced features (such as the implementation of "Intelligent Agent" or XBRL). The use of this technology makes it easier for users to access information contained in the company's website. This category of technology is said to be of quality if the company applies sophisticated technology on the company's website. The more qualified and sophisticated the higher the index with a maximum score of 18 or 20 percent.

User Support (user support), this user support category is related to services and facilities provided on the company's website to facilitate users and investors when accessing information. Services and facilities such as search and navigation media search tools (help and FAQ, links to homepage, site map, site search) besides that, clicks are needed by users to access company financial information. This user support component will be even higher if the company provides services and facilities on the website to facilitate users in accessing information. The more facilities provided on the company's website, the index will be higher with a maximum score of 15 or 20 percent.

\section{Methodology of research}

\subsection{Types of research}

This type of research uses content analysis with qualitative ties. The research was conducted on the websites of conventional banking companies that went public in Indonesia, Malaysia and Singapore, which were registered in www.idx.co.id, www.bursamalaysia.com, and www.sgx.com in 2017.

\subsection{Variable}

The explanation for each component is as follows:

1. Content, in this category includes components of financial information such as balance sheet reports, profit losses, cash flows, and changes in financial position and company sustainability reports. Financial information disclosed in html form has a high score compared to pdf format, because html information makes it easier for information users to access financial information faster.

2. Timeliness, when a company's website can provide timely information, the higher the index.

3. Technology Utilization, this component is related to the use of technology that cannot be provided by print report media and the use of multimedia technology media, analysis tools (for example, Excel's Pivot Table), advanced features (such as implementation of "Intelligent Agent" or XBRL).

4. User Support, the company's website index is higher if the company optimally implements all facilities in the company's website such as: media search and navigation/search and navigation tools (such as $F A Q$, links to homepage, site map, site search).

\subsection{Population and Samples}

The population studied was local banking companies that went public in Indonesia, Singapore and Malaysia. Based on the purposive sampling method, the samples to be used are 26 companies in Indonesia, 5 companies in Singapore, and 9 companies in Malaysia.

\section{Results and discussions}

\section{Index of Internet Financial Reporting}

Based on the descriptive analysis of local banking companies that went public in Indonesia, the highest index of the Internet Financial Reporting (IFR) was 84.20 percent, namely Bank Negara Indonesia (Persero) Tbk, while the lowest index of the Internet Financial Reporting (IFR) was 61 , 46\%, namely Bank Capital Indonesia Tbk. The average value of the Internet Financial Reporting (IFR) index in Indonesia is 72.69 percent, greater than the average value of local banking companies that go public in Singapore and Malaysia. This shows that the quality of Internet Financial Reporting (IFR) in Indonesia is quite good. The website of a local banking company that goes public in Indonesia has revealed quite complete financial 
information for investors even though in PDF form, but the quality of banking websites in Indonesia is more used to explain the company's products and services.

Table 1. Descriptive IFR Indonesian Banking

Descriptive Statistics IFR Perbankan Indonesia

\begin{tabular}{|l|l|l|l|l|l|}
\hline & $\mathrm{N}$ & Minimum & Maximum & Mean & Std. Deviation \\
\hline Content & 26 & .79 & 1.00 & .9246 & .07431 \\
Timeliness & 26 & .75 & .89 & .8204 & .04600 \\
Technology & 26 & .50 & .85 & .7662 & .07468 \\
UseSupport & 26 & .51 & .79 & .6977 & .06707 \\
Valid N (listwise) & 26 & & & & \\
\hline
\end{tabular}

Process data: SPSS. 22

Table 2. Descriptive IFR Banking Singapore

Descriptive Statistics IFR Perbankan Singapore

\begin{tabular}{|l|l|l|l|l|l|}
\hline & $\mathrm{N}$ & Minimum & Maximum & Mean & Std. Deviation \\
\hline Content & 5 & .05 & 1.00 & .5800 & .44944 \\
Timeliness & 5 & .00 & .89 & .4889 & .36515 \\
Techology & 5 & .17 & .50 & .4000 & .14907 \\
UseSupport & 5 & .29 & .71 & .4286 & .17496 \\
Valid N (listwise) & 5 & & & & \\
\hline
\end{tabular}

Process data: SPSS.22

Based on the descriptive analysis of local banking companies that went public in Singapore, the highest index of the Internet Financial Reporting (IFR) was 65.6 percent, namely The Development Bank of Singapore Limited, while the lowest index of the Internet Financial Reporting (IFR) was 26, 9 namely the Hong Kong and Shanghai Banking Corporation Limited. The average value of the Internet Financial Reporting (IFR) index in Singapore is equal to 47.44 percent, smaller than the average value of local banking companies that go public in Indonesia and Malaysia. This shows that the quality of the Internet Financial Reporting (IFR) in Singapore is still uneven, the company's website does not vary. Only a few corporate websites that disclose financial information in full and many of these websites do not apply good technology.

Table 3. Descriptive IFR Banking Malaysia

Descriptive Statistics IFR Perbankan Malaysia
\begin{tabular}{|l|l|l|l|l|l|}
\hline & $\mathrm{N}$ & Minimum & Maximum & Mean & Std. Deviation \\
\hline Content & 9 & .25 & .90 & .6500 & .22361 \\
Timeliness & 9 & .22 & .67 & .4198 & .17372 \\
Technology & 9 & .33 & .50 & .4815 & .05556 \\
UseSupport & 9 & .43 & .57 & .4444 & .04762 \\
Valid N (listwise) & 9 & & & & \\
\hline
\end{tabular}

Process data SPSS 22

Based on the descriptive analysis of local banking companies that went public in Malaysia, the highest index of the Internet Financial Reporting (IFR) was 62.38 percent, namely Malayan Banking Berhad, while the lowest index of the Internet Financial Reporting (IFR) was 35.02 percent, namely Rashid Hussein Bank Berhad. The average value of the Internet Financial Reporting (IFR) index in Malaysia is 49.89 percent, which is greater than the average value of local banking companies that go public in Singapore. This shows that the quality of the Internet Financial Reporting (IFR) in Malaysia has been quite good and varied. The website of a local banking company that goes public in Malaysia has revealed quite complete financial information for investors.

Based on descriptive results, the average value of the largest Internet Financial Reporting (IFR) index is Indonesia at $\mathbf{7 2 . 6 9}$ percent, then Malaysia at 49.89 percent and Singapore at 47.44 percent. This shows 
that the quality of Internet Financial Reporting (IFR) banking companies in Indonesia is better than Singapore and Malaysia. The website of a banking company in Indonesia is more complete in presenting financial information and company information even though the average only displays two languages (Indonesian and English) and the website of a banking company in Indonesia displays more complete financial information in PDF format. Although it has been quite good at providing support to users in accessing the company's website, it has not implemented much technology on the company's website, because it displays more banking products sold. While the websites of banking companies in Singapore and Malaysia, in addition to presenting financial information in PDF form, are also lacking in applying the use of technology on the company's website.

\section{Content}

Based on the descriptive table on local banking companies that go public in Indonesia with a total of 25 companies, the highest value of content (content) is 90 percent owned by 5 companies, while the lowest value of content components is 70 percent owned by 17 companies. This shows that the quality of the Internet Financial Reporting (IFR) in the content component on the website of local banking companies in Indonesia is quite good and reveals quite complete financial information for investors in the form of annual reports and quarterly reports from several periods even though in PDF form, such as position reports finance, financial performance reports, cash flow reports, and some websites also provide financial highlights, company leadership reports and information about shareholders. In addition, information about the company is also quite complete by displaying the company's mission, contacts, management structure and corporate social responsibility. But only a few of the company's websites provide stock information, such as current stock prices and historical shares.

Based on the descriptive analysis on local banking companies that go public in Singapore, the highest value of content components is 100 percent, namely United Overseas Bank, while the lowest value of content components is $5 \%$, namely Keppel Tat Lee Capital Bank. This shows that the quality of Internet Financial Reporting (IFR) on content components on manufacturing companies' websites in Singapore is still lacking in disclosing complete financial information for good investors, such as financial position reports, financial performance reports, cash flow reports, and some websites also provide financial company highlights. However, there are not many company websites that disclose quarterly reports, besides that information about the company is also more that only shows the composition of the company management while the vision, mission, contacts and corporate social responsibility are not widely presented. But quite a number of company websites that provide stock information, such as current and historical stock prices.

\section{Timeliness}

Based on the descriptive analysis of local banking companies that go public in Indonesia, the highest value of timeliness component is 78 percent owned by Bank Negara Indonesia (Persero) Tbk, while the lowest value of timeliness component is 0 owned by the State Savings Bank (Persero) Tbk. This shows that the quality of the Internet Financial Reporting (IFR) on the timeliness component on the website of a local banking company in Indonesia is not good enough because many company websites do not update the information presented. Many press releases presented are out of date, updated more than a month ago and even longer, there are even company websites that do not present press releases. Nearly 50 percent of company websites have reported the latest quarterly reports that have not been audited, but only a small portion of websites that provide stock information are routinely updated.

Based on the descriptive analysis of the local banking companies that went public in Singapore, the highest value of the timeliness component was 89 percent, namely The Development Bank of Singapore Limited, while the lowest value of the timeliness component was 0 , namely The Hong Kong and Shanghai Banking Corporation Limited. This shows that the quality of the Internet Financial Reporting (IFR) on the timeliness component on a banking company's website in Singapore is quite good because many corporate websites are inconsistent in updating the information presented. Some company websites present press releases but many are not updated.

Based on the descriptive analysis on local banking companies that went public in Malaysia, the highest value of timeliness component was 67 percent, there were two companies, Affin Bank Berhad and 
Malayan Banking Berhad, while the lowest value of timeliness component was 22 percent, 3 companies namely Public Bank Berhad, Rashid Hussein Bank Berhad and SME Bank Malaysia Berhad. This shows that the quality of the Internet Financial Reporting (IFR) on the timeliness component on a banking company's website in Malaysia is quite good because many company websites have updated the information presented. Although many company websites present press releases but many are out of date, updated more than a month ago and even longer. The stock quotes presented by the company's website are consistently updated, but most do not provide stock quote information. Some company websites have reported the latest quarterly reports and there are companies that do not present company vision reports / future estimates.

\section{Technology}

Based on descriptive analysis on local banking companies that go public in Indonesia, the value of the technology component of all banking companies in Indonesia has a value of 83 percent. This shows that the quality of the Internet Financial Reporting (IFR) on component technology on the website of manufacturing companies in Indonesia is good because the company's website has implemented technologies such as advanced features (XBRL), provides analytical tools and online feedback and support but does not provide presentation slides. However, many company websites have used technology multimedia such as images, audio and video so the website is more attractive.

Based on descriptive analysis on local banking companies that went public in Singapore, the highest value of component technology was $50 \%$ owned by three companies, namely The Development Bank of Singapore Limited, The Hong Kong and Shanghai Banking Corporation Limited, and Keppel Tat Lee Capital Bank. While the value of component technology is the lowest of 20 percent, namely Oversea-Chinese Banking Corporation. This shows that the quality of the Internet Financial Reporting (IFR) on the component technology on the website of a local banking company in Singapore is quite good because many corporate websites have used multimedia technology such as images, audio and video so that the website is more interesting, quite a lot of analytical tools, online feedback and support and presentation slides. But there is no company website that applies technology such as advanced features (XBRL).

Based on the descriptive analysis on local banking companies that went public in Malaysia, the highest value of component technology was 50 percent owned by 8 companies, while the lowest component technology value was 33.3 percent, namely Hong Leong Bank Berhad. This shows that the quality of the Internet Financial Reporting (IFR) on the component technology on the website of a banking company in Malaysia is quite good because the company's website has implemented technologies such as advanced features (XBRL), there are only a few corporate websites that provide analytical tools and online feedback. But overall the websites of Malaysian banking companies have utilized multimedia technologies such as images, audio and video so that the website is more attractive.

\section{User Support}

Based on descriptive analysis on local banking companies that go public in Indonesia, the highest value of user support components is $100 \%$ owned by 11 companies, while the lowest value of user support components is 71 percent owned by two companies namely Bank Capital Indonesia Tbk and Bank Bukopin Tbk. This shows that the quality of the Internet Financial Reporting (IFR) on the component of user support on the website of a banking company in Indonesia is quite good because all company websites have provided download menus, many company websites provide a menu link to the main page, sitemap, and site search and do not many clicks are needed to access financial information, and provide help and frequently asked questions, but there are some companies that do not provide a menu link to the top.

Based on a descriptive analysis of local banking companies that go public in Singapore, the value of the component of the user supports the highest of 71 percent, namely Keppel Tat Lee Capital Bank, while the value of component user support is the lowest of 29 percent owned by two companies namely The Development Bank of Singapore Limited and Oversea-Chinese Banking Corporation. This shows that the quality of the Internet Financial Reporting (IFR) in the user support component on the website of a banking company in Singapore is quite good because all company websites have provided download menus, many company websites that provide a menu link to the main page, sitemap, and help and frequently asked question, but not many company websites that provide a menu link to the top, and site search. 
Based on a descriptive analysis of local banking companies that went public in Malaysia, the value of the component of the user support was the highest at 57 percent, namely Alliance Bank Malaysia Berhad, while the value of the component of user support was as low as 43 percent owned by 8 companies. Reporting (IFR) on the component of user support on the website of a local banking company in Malaysia is not good enough because only about 10 percent of company websites provide a menu of links to the top, sitemap, and site search, and only a portion of company websites that provide help and frequently asked questions. However, all company websites have provided a download menu

\section{Conclusions}

1. The overall quality of the Internet Financial Reporting (IFR) in local banking companies that go public in Indonesia is higher than the quality of Internet Financial Reporting (IFR) in local banking companies that go public in Singapore and Malaysia.

2. The quality of Internet Financial Reporting (IFR) in the content component of banking companies that go public in Indonesia is higher than the quality of Internet Financial Reporting (IFR) in local banking companies that go public in Singapore and Malaysia.

3. The quality of Internet Financial Reporting (IFR) on timeliness components in local banking companies that go public in Indonesia is higher than the quality of Internet Financial Reporting (IFR) in local banking companies that go public in Singapore and Malaysia.

4. The quality of the Internet Financial Reporting (IFR) on the component of technology in local banking companies that go public in Indonesia is higher than the quality of the Internet Financial Reporting (IFR) in local banking companies that go public in Singapore and Malaysia.

5. The quality of Internet Financial Reporting (IFR) in the component of user support in local banking companies that go public in Indonesia is higher than the quality of Internet Financial Reporting (IFR) in local banking companies that go public in Singapore and Malaysia.

\section{Suggestions}

1. For researcher, hope the next researcher will expand the period or add samples by making comparisons with other countries.

2. For Companies, local banking companies that go public in the countries of Indonesia, Singapore and Malaysia are able to increase the disclosure of company information through the internet in accordance with the index of Internet Financial Reporting (IFR) which includes content, timeliness, technology and user support.

\section{References}

1. Almilia, L. S. (2015). Comparing internet financial reporting practices: Indonesia, Malaysia, Singapore, Japan and Australia. Int. J. Business Information Systems, Vol. 20, No. 4.

2. Almilia, L. S. (2009). Determining Factors of Internet Financial Reporting in Indonesia. Journal Accounting \& Tax, Vol. 1 No.1

3. Ariff, A. M., Ghanem, Bin Hasan O., \& Hashim, A. A. (2018). Corporate Ownership, Internet Penetration and Internet Financial Reporting: Evidence from the Gulf Cooperation Council Countries. Asian Journal of Business and Accounting, Vol. 11, No.1.

4. Cheng, A., Lawrence, S. \& Coy, D., (2000). Measuring the Quality of Corporate Financial Websites: A New Zealand study, Paper presented at the 12th Asian-Pacific Conference on International Accounting Issues, Beijing.

5. Davey, H., Homkajohn, K. (2004). Corporate Internet Reporting: An Asian Example. Business Perspective Problems and Perspectives in Management, Vol. 2.

6. Harnovinsah, Alamsyah, Sustari. (2017). The Mediation Influence of Value Relevance of Accounting Information, Invesment Decision and Devidend Policy on the Relationship between Profitability and the Company's Value. Jurnal Akuntansi, Volume XXI, No. 02, P: 170-183

7. Handayani, E., Almilia, L. S. (2013). Internet Financial Reporting: Studi Komparasi Perusahaan Manufaktur yang Terdaftar di Bursa Eefek Indonesia dan Bursa Eefek Malaysia. Jurnal Bisnis dan Ekonomi (JBE), Vol. 20, No. 2, P: $100-112$ ISSN: 1412-3126 
8. Khan, M. N. A. A., Ismail, N. A. (2011). The Level of Internet Financial Reporting of Malaysian Companies. Asian Journal of Accounting and Governance, vol. 2, P: 27-39.

9. Khan, Mohd Noor A. A., Ismail, N. A. (2012). Bank Officers' Views of Internet Financial Reporting in Malaysia. Procedia - Social and Behavioral Sciences 57, $75-84$

10.Kuruppu, N., Oyelere, P., Jabri, H. A. (2015). Internet Financial Reporting and Disclosure Practices of Publicly Trade Corportions: Evidence From Sri Lanka. Journal Accounting \& Taxation Vol. 7, No. 1, pp. 7591.

11.Mohammadi, S. M. (2014). The Relationship between Financial Reporting Quality and Investment Efficiency in Tehran Stpck Exchange. International Journal of Academic Research in Business and Social Sciences. Vol. 4, No. 6, 104-113.

12.Ojah, K., Mokoteli, T. M. (2012). Internet financial reporting, infrastructures and corporate governance: an international analysis. Review of Development Finance, 69-83.

13.Pertiwi, I. F. P. (2017). Kinerja Keuangan dan Internet Financial Reporting Index (IFRI): Sebuah Studi Relevansi Pada Sektor Perbankan Syariah di Kawasan ASEAN. Jurnal Ekonomi dan Perbankan Syariah Vol. 4 No. 1.

14.Reskino \& Sinaga N. N. J. (2016). Kajian Empiris Internet Financial Reporting dan Praktek Pengungkapan. Media Riset Akuntansi, Auditing \& Informasi, Vol. 16 No. 2.

15.Wiwik, U., Nugroho, L. (2017). "Fundamental versus technical analysis of investment: Case study of investors decision in Indonesia Stock Exchange". The Journal of Internet Banking and Commerce, ISSN: 1204-5357.

16.Wardhanie, N. S. (2012). Analisis Internet Financial Reporting Index ; Studi Komparasi Antara Perusahaan High-tech dan Non High-tech di Indonesia. Jurnal Reviu Akuntansi dan Keuangan, Vol.2 No. 2, 287-300.

17.Widari, P. P., Saifi, M., Nurlaily, F. (2018). Analisis Internet Financial Reporting (IFR) (Studi Pada Perusahaan Manufaktur Yang Go Public di Indonesia, Singapura, dan Malaysia). Jurnal Administrasi Bisnis (JAB)|Vol.56 